\title{
Performance and carcass traits in the diallel crossing of pacu and tambaqui ${ }^{1}$
}

\author{
Rafael Vilhena Reis Neto ${ }^{2}$, Moacyr Antonio Serafini ${ }^{3}$, Rilke Tadeu Fonseca de Freitas ${ }^{2}$, \\ Ivan Bezerra Allaman ${ }^{4}$, Natália Michele Nonato Mourad², Aline de Assis Lago²
}

\footnotetext{
${ }^{1}$ Support: CNPq and FAPEMIG.

${ }^{2}$ Universidade Federal de Lavras - DZO.

${ }^{3}$ Instituto Federal do Espirito Santo - Campus Santa Teresa.

${ }^{4}$ Universidade Estadual de Santa Cruz - UESC.
}

\begin{abstract}
With the purpose of evaluating the changes and the degree of heterosis on performance and carcass traits of fish from the diallel crossing between Pacu and Tambaqui, four genetic groups were generated through hormonal induction: pacu, tambaqui, tambacu and paqui. For 196 days, 400 juveniles of each genetic group were stocked in a pond divided into four parts of equal size, one for each group. At the end of this period, when the fish weighed on average $1024 \mathrm{~g}( \pm 115.52 \mathrm{~g})$, 20 specimens of each genetic group were sampled, weighed, measured: head length; standard length; body height; and width; and also processed resulting in following body yield: viscera; carcass; head; fillet; rib; residue and skin yields. There was positive heterosis for body weight, viscera and skin yield and head measures and negative heterosis for carcass and filet yield and body width, indicating that the hybrids have better performance on weight gain, but are inferior in relation to the carcass conformation.
\end{abstract}

Key Words: body yield, heterosis, hybrids, morphometry, roundfish

\section{Introduction}

In South America, Brazil is the second country in importance in aquaculture production, only below Chile (IBAMA, 2007). Compared with other national activities, aquaculture, which grows on average $16 \%$ per year, features superior results to those of extractive fishing and also excels in relation to the production of poultry, pigs and cattle, which, in recent years, had average growth rates of $9 \%, 13 \%$ and $-8 \%$ per year, respectively, considering the period from 2007 to 2009 (Ministry of Fisheries and Aquaculture, 2010).

Due to the ease of cultivation, good growth performance and meat quality (Kubitza, 2004), round fish (species and hybrids of the genera Colossoma and Piaractus) represent $82 \%$ of the amount of native fish cultivated in Brazil (IBAMA, 2007). Along with the preference of producers for cultivation of these species and the drive for productivity increase, the interest in fish with superior genetics has increased.

Studies on the body yields of fish are of great value to the industry of fish and fish farmers. Carcass, fillet and ribs yield are the most important because they represent the useful part of fish used for human consumption (Souza, 2008). In this sense, one should take into account the species, body weight, and the anatomical format of fish, as well as the efficiency of the filleting machine and/or dexterity of the filleter, among others (ContrerasGusmán, 1994).

Alternative strategies to produce fish with the best carcass traits have focused primarily on the use of body measurements as selection criteria related mainly to fillet yield (Silva et al., 2009). The morphometric measurements can be used in the evaluation of carcass quality as a selection criterion in genetic improvement programs and to get correlated response on fish body component yield (Rutten et al., 2004).

Although the production of interspecific hybrids in Brazil has become a common practice in fish farms, and although it has already been shown that the hybridization between species of roundfish is feasible, changes in performance and morphometric and carcass characteristics arising from the production of hybrids involving crossing between the pacu and tambaqui species have not been properly evaluated yet.

The objective of this study was to evaluate the changes and the degree of heterosis on performance and carcass and morphometric characteristics of fish from the diallel crossing between pacu Piaractus mesopotamicus and tambaqui Colossoma macropomum. 


\section{Material and Methods}

The experiment was carried out at the Department of Fish Farming of Instituto Federal do Espírito Santo, Campus Colatina, located $17 \mathrm{~km}$ from Colatina, state of Espírito Santo, Brazil, from October 2007 to May 2008. Genetic groups generated from the complete diallel crossing were used in this research. The crossings were performed between pacu and tambaqui, i.e., the product of the female pacu and male pacu gametes (pacu); female tambaqui and male tambaqui (tambaqui), female tambaqui and male pacu (tambacu) and female pacu and male tambaqui (paqui), produced by means of hormonal induction according to the protocol described by Andrade \& Yasui (2003). The gametes of five males and five females of each species were used.

Initially, the embryos were incubated separately by genetic groups and, after five days of hatching, the larvae were transferred to earth ponds specially prepared for a density of 200 larvae $/ \mathrm{m}^{2}$, with one pond for each genetic group. After 140 days of cultivation, 200 juveniles with a mean weight of $70 \mathrm{~g}$ of each genetic group were randomly collected and stocked in a pond divided with polypropylene screen $(9 \times 9 \mathrm{~mm})$ in four equal parts $(6 \times 11 \times 1.5 \mathrm{~m})-$ one for each genetic group - with individual water supply. The fish remained in this pond for 196 days. During this period, monthly samplings of 20 fish for each generic group were performed for other studies, so that at the end of the experiment the genetic groups were stocked at a low fish density per $\mathrm{m}^{2}$.

After being transferred to the pond, the larvae received natural feeding and commercial diet extruded and ground containing $550 \mathrm{~g}$ of crude protein (CP) per $\mathrm{kg}$. The feed were supplied at the rate of $180 \mathrm{~g} / \mathrm{kg}$ of biomass three times a day until the fish reached $10 \mathrm{~g}$ of live weight. Later, an extruded diet containing $450 \mathrm{~g} \mathrm{CP} / \mathrm{kg}$ of the diet at the rate of $80 \mathrm{~g} / \mathrm{kg}$ of biomass was supplied three times a day until the juveniles were transferred to the pond divided with polypropylene screen. The fish were fed an extruded commercial diet specific for the growth and slaughter phases, with $350 \mathrm{~g}$ and $280 \mathrm{~g} \mathrm{CP} / \mathrm{kg}$ of feed, respectively, supplied according to the biomass of each genetic group, which varied from $50 \mathrm{~g} / \mathrm{kg}$ in the first week to $10 \mathrm{~g} / \mathrm{kg}$ in the last week.

Water quality variables were monitored as follows: temperature measured on a daily basis at the beginning and end of the day by means of a "mercury thermometer"; the oxygen was measured on a weekly basis, using HI 98186 Dissolved Oxygen Meter; the $\mathrm{pH}$ was measured on a weekly basis, with the aid of a $\mathrm{pH}$ meter (Table 1).

In general, the physical and chemical parameters of the water remained within the limits recommended for good fish performance (Boyd, 1992; Popma \& Phelps, 1998; Kubitza, 2003).

At the end of the experiment, 20 specimens of each genetic group were stunned and slaughtered by marrow section with a $15 \mathrm{~cm}$ stainless knife. The knife was inserted through one of the opercula at $30^{\circ}$, until reaching the marrow for section. Later, the fish were weighted, measured, cooled down and processed for morphometric analysis and yield at processing.

The measures used in the morphometric evaluation were: head length (HL), from the front end to the operculum caudal rim; standard length (SL), from the front end of the head to the lesser peduncle perimeter (caudal fin insertion); body height, measured in front of the first radius of the dorsal fins (BH); and body width, measured in the region of the first radius of the dorsal fin (BW). The standard length (SL) was measured in centimeters with an ictiometer. For the other measures, a gauge caliper with a millimeter scale (mm) was used. Besides the morphometric measures, the following morphometric ratios were calculated: head length/standard length (HL/SL); head length/body height (HL/BH); body height/standard length $(\mathrm{BH} / \mathrm{SL})$; body width/standard length; body width/head length (BW/HL); and body width/body height (BW/BH).

Table 1 - Means of the minimum and maximum temperature, dissolved oxygen and water $\mathrm{pH}$ values during the experimental period

\begin{tabular}{|c|c|c|c|c|c|c|}
\hline \multirow{2}{*}{ Period (days) } & \multicolumn{2}{|c|}{ Temperature $\left({ }^{\circ} \mathrm{C}\right)$} & \multicolumn{2}{|c|}{ Dissolved oxygen $(\mathrm{mg} / \mathrm{L})$} & \multicolumn{2}{|c|}{$\mathrm{pH}$} \\
\hline & Minimum & Maximum & Minimum & Maximum & Minimum & Maximum \\
\hline 1 to 28 & 25.5 & 29.3 & 4.4 & 5.3 & 6.8 & 7.2 \\
\hline 29 to 56 & 24.2 & 27.2 & 4.4 & 4.9 & 6.6 & 7.0 \\
\hline 57 to 84 & 26.1 & 29.2 & 4.2 & 4.9 & 6.4 & 7.2 \\
\hline 85 to 112 & 24.8 & 27.6 & 4.0 & 4.7 & 6.6 & 7.0 \\
\hline 113 to 140 & 27.0 & 30.0 & 3.5 & 4.2 & 6.8 & 7.4 \\
\hline 141 to 168 & 24.7 & 29.8 & 3.7 & 4.2 & 6.8 & 6.8 \\
\hline 169 to 196 & 24.5 & 28.5 & 3.6 & 4.0 & 6.6 & 7.2 \\
\hline Overall average & $25.26( \pm 1.00)$ & $28.80( \pm 1.08)$ & $3.9( \pm 0.41)$ & $4.6( \pm 0.47)$ & $6.7( \pm 0.15)$ & $7.1( \pm 0.19)$ \\
\hline
\end{tabular}


The methodology proposed by Caraciolo et al. (2001) was used to obtain weights and yields of the products and byproducts resulting from the processing.

With the fish whole and cold, the skin was removed along with the scales using a pair of pliers in the rostrocaudal direction. For so, four shallow cuts were made on the ends of the fish body: 1) vertical cut after the operculum; 2) dorsal cut from the base of the head to the caudal fin, close to the dorsal fin; 3) vertical cut before the caudal fin; and 4) caudal cut to the head in the abdominal end, passing by the anal and pelvic fins. After that, with the use of a filleting knife, the fillet with the ribs, which were separated later, were separated from the backbone. The viscera were then removed. The head was sectioned from the backbone with a vertical cut after the operculum. Thus, the viscera, head, fillet, ribs, skin and residue (backbone and fins) were obtained and weighted. The yield of each product was calculated as the ratio between the weight of the body part being evaluated, divided by the weight of the slaughtered whole fish. The following yields were obtained: viscera yield $($ YVISC) $=$ viscera weight/slaughter weight; carcass yield $($ YCAR $)=$ carcass weight/slaughter weight; head yield $($ YHEAD $)=$ head weight/slaughter weight; fillet yield $($ YFILL $)=$ fillet weight/slaughter weight; rib yield $($ YRIB $)=$ rib weight/slaughter weight; residue yield $($ YRES) = residue weight/slaughter weight; skin yield $($ YSKIN $)=$ skin weight $/$ slaughter weight .

Body weight and yields were submitted to variance analysis, with $\alpha=0.05$, according to the following statistic model:

$$
Y i j k=M+S A i+G G / S A j / i+e i j k
$$

in which: Yijk $=$ observation $\mathrm{k}$ of genetic group $\mathrm{j}$ of mating $\mathrm{i} ; \mathrm{M}=$ means of all observations; $\mathrm{SAi}=$ effect of the mating system $i$, in which $i=1$ (purebred) and 2 (hybrids); $\mathrm{GG} / \mathrm{SAj} / \mathrm{i}=$ effect of the genetic group $\mathrm{j}(1=$ pacu; $2=$ tambaqui; 3 = tambacu; and 4 = paqui), in the mating system $\mathrm{i}$; eijk $=$ residual random effects.

The covariable slaughter weight was included in the model for the morphometric data, i.e., b (xijk - Mx), in which $b$ is the linear regression coefficient of the morphometric variable according to the slaughter weight; xijk is the slaughter weight of observation $\mathrm{k}$ of genetic group $\mathrm{j}$ of mating I; and $\mathrm{Mx}$ is the overall mean of slaughter weight.

The analyses were performed by means of software package SAEG (Sistema Para Análise Estatística e Genética, version 9.0).

Heterosis was calculated for each characteristic from the adjusted means, by the following formula: $\mathrm{H}=$ $[(\mathrm{PQ}+\mathrm{TC}) / 2]-[(\mathrm{PC}+\mathrm{TQ}) / 2] /[(\mathrm{PC}+\mathrm{TQ})] / 2$, in which:
$\mathrm{H}=$ heterosis; $\mathrm{PQ}=$ paqui; $\mathrm{TC}=$ tambacu; $\mathrm{PC}=$ pacu; $\mathrm{TQ}=$ tambaqui; $(\mathrm{PQ}+\mathrm{TC}) / 2=$ means of the hybrids; $(\mathrm{PC}+\mathrm{TQ}) / 2=$ means of the purebreds.

\section{Results and Discussion}

The values obtained for carcass yield in pacu (0.892) were similar to that found by Faria et al. (2003), of 0.889 . In this study, the fillet yield (0.319), for the same species, was lower than the 0.51 reported by Faria et al. (2003), and higher than the 0.241 obtained by Bombardelli et al. (2007) (Table 2). This divergence of values for the fillet yield may be related to the filleting method used in experiments, which may or may not aggregate the rib to the fillet.

The means of the hybrids were different $(\mathrm{P}<0.05)$ from the means of the purebreds for most characteristics (Table 2), with the exception of yields of head (YHEAD), ribs (YRIB) and residue (YRES), suggesting that the phenotypic expression of these characteristics may be controlled by additive genetic effect. Silva et al. (2010) also stated that, in tilapia, some carcass characteristics are influenced mainly by the additive genetic effect.

The hybrids present higher means $(\mathrm{P}<0.05)$ than purebreds for final weight, viscera (YVISC) and skin (YSKIN) yields, resulting in positive heterosis values of $0.072 ; 0.055$; and 0.072 , respectively (Table 2 ). However, hybrids presented lower $(\mathrm{P}<0.05)$ eviscerated carcass (YCAR) and fillet (YFILL) yields, revealing negative heterosis of -0.006 and -0.073 , respectively, for these characteristics. The worse YCAR of hybrids was a direct consequence of its higher viscera ratio when compared with purebreds, and the higher YSKIN may have contributed to a lower mean yield of hybrid fish fillet.

In different populations of African catfish (Clarias gariepinus), the positive heterosis effect (0.02) was also found in the first 5 weeks of evaluation for body weight (Wachirachaikarn et al., 2009), and in a study carried out evaluating the diallel crossing of four lineages of common carp, Nielsen et al. (2010) found mean positive heterosis of $0.094 ; 0.109$; and 0.201 for body weight during the cultivation period.

There were differences $(\mathrm{P}<0.05)$ between the hybrids for weight at the end of cultivation for viscera (YVISC), carcass (YCAR), fillet (YFILL) and skin (YSKIN) yields (Table 2), indicating that the performance of the hybrids for these characteristics depends on the species used in the mating (female or male). It was observed that the hybrid tambacu presented higher weight at the end of the cultivation, higher YVISC and YSKIN $(\mathrm{P}<0.05)$ and lower YCAR and YFILL than paqui $(\mathrm{P}<0.05)$. By observing the 
results obtained for purebred fish (pacu and tambaqui), it was verified that tambaqui was heavier, with higher YCAR, YHEAD and YSKIN and lower YVISC, YFILL and YRIB than pacu $(\mathrm{P}<0.05)$, and did not differ $(\mathrm{P}>0.05)$ from YRES.

By associating these results, it was verified that the final weight and fillet and skin yields of the hybrids are related to the performance of the mother species. The female tambaqui promotes higher final weight and YSKIN. The female pacu promotes higher YFILL for its progeny. On the other hand, YVISC and YCAR seem to be influenced by the species used as male in the mating. Thus, male pacu, a species with higher YVISC and lower YCAR, produced hybrids with higher YVISC and lower YCAR. The contrary happened when tambaqui was used as male parent. The results observed are related to the concept of maternal and paternal effect, which can be defined as the contribution, influence or impact on the phenotype of an individual, directly attributable to the maternal or paternal characteristics, which can arise from genetic or environmental causes (Hohenboken, 1964; Weigensberg et al., 1998; Bradford, 1972).

At the end of cultivation, the weight of the hybrid tambacu was higher than all other genetic groups studied, $28.7 \%$ higher than the means of the purebreds (specific heterosis) and $16 \%$ higher than the means of the tambaqui. However, it was also one of the genetic groups with the worst processing yields. Calculating the amount of fillet (in grams) produced for each group, we can observe $289.5 \mathrm{~g}$ for pacu; $275.3 \mathrm{~g}$ for tambaqui; $332.3 \mathrm{~g}$ for tambacu; and $231.9 \mathrm{~g}$ for paqui. Therefore, even with the lower YFILL, tambacu produced $14.8 \%$ more fillet in absolute value than pacu; or $17.7 \%$ more than the means of the purebreds (286.4 g) (Table 2). These results show that there was a fillet weight increase for tambacu in relation to pacu and to the means of the purebreds, as a consequence of the heterosis observed for final weight.

The means of the hybrids was different $(\mathrm{P}<0.05)$ from the means of the purebreds for most measures and morphometric ratios, with the exception of the standard length (SL) and the ratio between the head length and body height $(\mathrm{HL} / \mathrm{BH})$ (Table 3 ). Comparing only the values of the morphometric measures (SL, HL, BH and $\mathrm{BW}$ ), it can be observed that the greater difference was related to body width. The hybrids presented BW $14.91 \%$ lower than the means of the purebreds, revealing negative heterosis $(\mathrm{P}<0.05)$ for this measure; but for $\mathrm{HL}$ and $\mathrm{BH}$, the heterosis was lower but positive, i.e., the hybrids presented, on average, $\mathrm{HL}(0.02)$ and $\mathrm{BH}(0.023)$ higher than the purebreds. As for standard length, the hybrids presented means $(\mathrm{P}>0.05)$ similar to purebreds, suggesting that the phenotypic expression of this morphometric measure is controlled by additive genetic effect.

Except for $\mathrm{HL} / \mathrm{BH}$, heterosis was significant for all morphometric ratios evaluated, positive for ratios $\mathrm{HL} / \mathrm{SL}$ (0.022), BH/SL (0.024) and HL/BW (0.2), and negative for $\mathrm{BW} / \mathrm{SL}(-0.148)$ and $\mathrm{BW} / \mathrm{BH}(-0.168)$, showing that the hybrids and purebreds differ as to body shape. The width/ length ratio represents the conformation of fillet (Boscolo et al., 2001). Costa (2011) states that the higher the width is, the higher the fillet yield of pacu. On the other hand,

Table 2 - Means, heterosis and P values for final weight (WEIG) and viscera (YVIS), carcass (YCAR), head (YHEA), fillet (YFILL), ribs (YRIB), skin (YSKIN) and residue (YRES) yield, according to the genetic group and mating system

\begin{tabular}{|c|c|c|c|c|c|c|c|c|}
\hline & WEIG (g) & YVIS & YCAR & YHEAD & YFILL & YRIB & YSKIN & YRES \\
\hline \multicolumn{9}{|c|}{ Purebreds } \\
\hline $\mathrm{PC}^{1}$ & $907.63 b$ & $0.108 \mathrm{a}$ & $0.892 b$ & $0.174 b$ & $0.319 \mathrm{a}$ & $0.183 a$ & $0.049 \mathrm{~b}$ & $0.166 \mathrm{a}$ \\
\hline TQ & $1069.5 \mathrm{a}$ & $0.087 \mathrm{~b}$ & $0.913 \mathrm{a}$ & $0.28 \mathrm{a}$ & $0.257 \mathrm{~b}$ & $0.154 b$ & $0.059 \mathrm{a}$ & $0.162 \mathrm{a}$ \\
\hline Mean & $988.55 \mathrm{~B}$ & $0.097 \mathrm{~B}$ & $0.902 \mathrm{~A}$ & $0.227 \mathrm{~A}$ & $0.288 \mathrm{~A}$ & $0.168 \mathrm{~A}$ & $0.054 \mathrm{~B}$ & $0.164 \mathrm{~A}$ \\
\hline \multicolumn{9}{|c|}{ Hybrids } \\
\hline $\mathrm{TC}$ & $1273.06 \mathrm{a}$ & $0.108 \mathrm{a}$ & $0.892 b$ & $0.226 a$ & $0.261 b$ & $0.178 \mathrm{a}$ & $0.061 \mathrm{a}$ & $0.167 \mathrm{a}$ \\
\hline PQ & $846.59 b$ & $0.098 \mathrm{~b}$ & $0.902 \mathrm{a}$ & $0.233 a$ & $0.274 \mathrm{a}$ & $0.17 \mathrm{a}$ & $0.055 \mathrm{~b}$ & $0.17 \mathrm{a}$ \\
\hline Mean & $1059.82 \mathrm{~A}$ & $0.103 \mathrm{~A}$ & $0.897 \mathrm{~B}$ & $0.229 \mathrm{~A}$ & $0.267 \mathrm{~B}$ & $0.174 \mathrm{~A}$ & $0.058 \mathrm{~A}$ & $0.168 \mathrm{~A}$ \\
\hline Heterosis & 0.072 & 0.055 & -0.006 & 0.009 & -0.072 & 0.031 & 0.072 & 0.026 \\
\hline \multicolumn{9}{|c|}{$\mathrm{P}$ values } \\
\hline $\mathrm{SA}(\mathrm{P} \times \mathrm{H})^{2}$ & 0.012 & 0.002 & 0.002 & 0.261 & 0.000 & 0.082 & 0.009 & 0.184 \\
\hline $\mathrm{P} / \mathrm{PC} \times \mathrm{TQ}$ & 0.000 & 0.000 & 0.000 & 0.000 & 0.000 & 0.000 & 0.000 & 0.191 \\
\hline $\mathrm{H} / \mathrm{TC} \times \mathrm{PQ}$ & 0.000 & 0.000 & 0.000 & 0.062 & 0.036 & 0.061 & 0.007 & 0.182 \\
\hline CV (\%) & 12.1 & 7.5 & 2.8 & 5.6 & 6.9 & 7.7 & 11.6 & 12.4 \\
\hline
\end{tabular}

Means followed by different lowercase letter, in the same column and mating system (purebreds or hybrids), differ the by the F test, with $\alpha=0.05$.

Means of purebreds and hybrids followed by different capital letters in the same column differ by the F test, with $\alpha=0.05$.

$\mathrm{CV}$ - coefficient of variation.

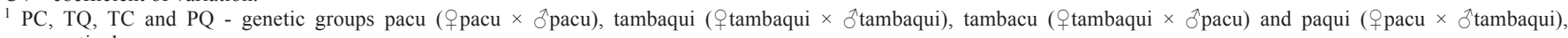
respectively.

${ }^{2} \mathrm{SA}(\mathrm{P} \times \mathrm{H})$ : Mating system - Purebred $\times$ Hybrid; $\mathrm{P} / \mathrm{PC} \times \mathrm{TQ}:$ genetic groups, $\mathrm{PC} \times \mathrm{TQ}$, in the pure mating system; $\mathrm{H} / \mathrm{TC} \times \mathrm{PQ}:$ genetic groups, TC $\times \mathrm{PQ}$, in the hybrid mating system. 
Table 3 - Means adjusted for the slaughter weight covariable, heterosis and P values of the measures (cm) and morphometric ratios according to the genetic group and mating system

\begin{tabular}{|c|c|c|c|c|c|c|c|c|c|c|}
\hline & $\mathrm{SL}^{2}$ & $\mathrm{HL}$ & $\mathrm{BH}$ & BW & $\mathrm{HL} / \mathrm{SL}$ & $\mathrm{BH} / \mathrm{SL}$ & $\mathrm{BW} / \mathrm{SL}$ & $\mathrm{HL} / \mathrm{BH}$ & HL/BW & $\mathrm{BW} / \mathrm{BH}$ \\
\hline \multicolumn{11}{|c|}{ Purebreds } \\
\hline $\mathrm{PC}^{1}$ & $27.80 \mathrm{~b}$ & $7.02 \mathrm{~b}$ & $14.41 \mathrm{~b}$ & $4.35 b$ & $0.25 \mathrm{~b}$ & $0.52 \mathrm{a}$ & $0.16 \mathrm{~b}$ & $0.49 b$ & $1.61 \mathrm{~b}$ & $0.30 \mathrm{~b}$ \\
\hline TQ & $28.95 a$ & $9.61 \mathrm{a}$ & $14.76 \mathrm{a}$ & $4.84 \mathrm{a}$ & $0.33 \mathrm{a}$ & $0.51 \mathrm{a}$ & $0.17 \mathrm{a}$ & $0.65 \mathrm{a}$ & $1.99 \mathrm{a}$ & $0.33 \mathrm{a}$ \\
\hline Mean & $28.37 \mathrm{~A}$ & $8.27 \mathrm{~B}$ & $14.59 \mathrm{~B}$ & $4.65 \mathrm{~A}$ & $0.29 \mathrm{~B}$ & $0.51 \mathrm{~B}$ & $0.16 \mathrm{~A}$ & $0.57 \mathrm{~A}$ & $1.78 \mathrm{~B}$ & $0.32 \mathrm{~A}$ \\
\hline \multicolumn{11}{|c|}{ Hybrids } \\
\hline $\mathrm{TC}$ & $28.48 \mathrm{a}$ & $8.53 \mathrm{a}$ & $14.81 \mathrm{a}$ & $3.78 \mathrm{a}$ & $0.30 \mathrm{a}$ & $0.52 \mathrm{a}$ & $0.13 \mathrm{a}$ & $0.58 \mathrm{a}$ & $2.26 \mathrm{a}$ & $0.26 \mathrm{a}$ \\
\hline PQ & $28.17 \mathrm{a}$ & $8.44 \mathrm{a}$ & $15.02 \mathrm{a}$ & $4.13 \mathrm{a}$ & $0.30 \mathrm{a}$ & $0.53 \mathrm{a}$ & $0.15 \mathrm{a}$ & $0.56 \mathrm{a}$ & $2.04 \mathrm{a}$ & $0.27 \mathrm{a}$ \\
\hline Mean & $28.33 \mathrm{~A}$ & $8.43 \mathrm{~A}$ & $14.91 \mathrm{~A}$ & $3.95 \mathrm{~B}$ & $0.30 \mathrm{~A}$ & $0.53 \mathrm{~A}$ & $0.14 \mathrm{~B}$ & $0.57 \mathrm{~A}$ & $2.13 \mathrm{~A}$ & $0.27 \mathrm{~B}$ \\
\hline Heterosis & -0.002 & $0.019 *$ & $0.023^{*}$ & $-0.149 *$ & $0.022 *$ & $0.024 *$ & $-0.148 *$ & -0.003 & $0.2 *$ & $-0.168^{*}$ \\
\hline \multicolumn{11}{|c|}{$\mathrm{P}$ values } \\
\hline $\mathrm{SA}(\mathrm{P} \times \mathrm{H})^{3}$ & 0.247 & 0.009 & 0.000 & 0.000 & 0.000 & 0.000 & 0.000 & 0.295 & 0.000 & 0.000 \\
\hline $\mathrm{P} / \mathrm{PC} \times \mathrm{TQ}$ & 0.000 & 0.000 & 0.000 & 0.000 & 0.000 & 0.171 & 0.006 & 0.000 & 0.000 & 0.001 \\
\hline $\mathrm{H} / \mathrm{TC} \times \mathrm{PQ}$ & 0.163 & 0.174 & 0.189 & 0.094 & 0.147 & 0.033 & 0.069 & 0.273 & 0.138 & 0.286 \\
\hline CV (\%) & 3.9 & 2.9 & 3.1 & 6.4 & 2.8 & 2.62 & 6.4 & 3.1 & 6.6 & 6.7 \\
\hline
\end{tabular}

Means followed by different lowercase letter, in the same column and mating system (purebreds or hybrids), differ the by the F test, with $\alpha=0.05$.

Means of purebreds and hybrids followed by different capital letters in the same column differ by the $\mathrm{F}$ test, with $\alpha=0.05$.

$\mathrm{CV}$ - coefficient of variation.

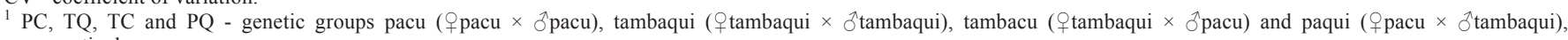
respectively.

${ }^{2} \mathrm{SL}$ - standard length; HL - head length; BH and BW - body height and width measured on the first radius of the dorsal fin, respectively; HL/SL, BH/SL, BW/SL, HL/BH, HL/BW, $\mathrm{BW} / \mathrm{BH}$ - ratios between the morphometric measures.

${ }^{3} \mathrm{SA}(\mathrm{P} \times \mathrm{H})$ : Mating system - Purebred $\times$ Hybrid; $\mathrm{P} / \mathrm{PC} \times \mathrm{TQ}$ : genetic groups, $\mathrm{PC} \times \mathrm{TQ}$, in the pure mating system; $\mathrm{H} / \mathrm{TC} \times \mathrm{PQ}:$ genetic groups, TC $\times \mathrm{PQ}$, in the hybrid mating system.

* Heterosis significant $(\mathrm{P}<0.05)$

Faria et al. (2003) observed that fish with a large head in comparison with the body present lower fillet yield, when compared with fish with a small head. Thus, the hybrids present the worst carcass conformation compared with purebreds (Table 2). Purebred animals presented higher $(\mathrm{P}<0.05)$ fillet and carcass yields.

Hybrids did not differ $(\mathrm{P}>0.05)$ as to morphometric measures and ratios, indicating that different species genders have no influence on the characteristics of hybrids produced. However, purebreds did not differ $(\mathrm{P}>0.05)$ as to the $\mathrm{BH} / \mathrm{SL}$ ratio. For the remaining morphometric measures and ratio, tambaqui presented higher values $(\mathrm{P}<0.05)$ than pacu, and the most expressive differences were observed for HL, of approximately $37 \%$, as well as in the morphometric ratios that involved in this measure, i.e., $\mathrm{HL} / \mathrm{SL}, \mathrm{HL} / \mathrm{BH}$ and HL/BW. Ratios HL/BH and HL/SL represent head proportion, so the tambaquis presented head slightly bigger in relation to the remaining groups.

The hybrids from the crossing of pacu and tambaqui presented a flatter and taller body shape, with longer head, when compared with the mean formats of the purebreds, regardless of the species used as female or male in the mating.

\section{Conclusions}

The diallel crossing between pacu and tambaqui resulted in positive heterosis for final weight, viscera and skin yield, mainly for the morphometric measures and ratios that made up head size; and presented negative heterosis for fillet and carcass yield, especially for the body width measures, which shows that the hybrids stand out in the matter of performance, but are not better than purebreds in relation to carcass conformation. However, in general, the better performance in weight gain of the hybrids compensates the worse body yields, generating an increase in absolute values in fillet size in relation to the means of the purebreds.

\section{Acknowledgements}

The authors thank Instituto Federal do Espírito Santo (IFES) - Campus Itapina and Campus Santa Teresa for the support during the experiment.

\section{References}

ANDRADE, D.R.; YASUI, G.S. O manejo da reprodução natural e artificial e sua importância na produção de peixes no Brasil. Revista Brasileira de Reprodução Animal, v.27, n.2, p.166-172. 2003.

BOMBARDELLI, R.A.; BENCKE, B.C.; SANCHES, E.A. Processamento da carne do pacu (Piaractus mesopotamicus) cultivado em tanques-rede no reservatório de Itaipu. Acta Scientiarum. Animal Sciences, v.29, n.4, p.457-463, 2007.

BOSCOLO, W.R.; HAYASHI, C.; SOARES, C.M. et al. Desempenho e características de carcaça de machos revertidos de tilápia do Nilo (Oreochromis niloticus), linhagem Tailandesa e Comum, nas fases inicial e de crescimento. Revista Brasileira de Zootecnia, v.30, n.5, p.1391-1396, 2001. 
BOYD, C. Water quality management for ponds fish culture in developments in aquaculture and fisheries science. 9.ed. New York: Elsevier, 1992. 183p.

BRADFORD, G.E. The role of maternal effects in animal breeding: VII. Maternal effects in sheep. Journal of Animal Science, v.35, n.6, p.1324-1334, 1972.

CARACIOLO, M.S.B.; KRUGER, S.R.; COSTA, F.J.C.B. Estratégias de filetagem e aproveitamento da carne do tambaqui. Panorama da Aquicultura, v.11, n.67, p.25-29, 2001.

CONTRERAS-GUZMÁN, E.S. Bioquímica de pescados e derivados. Jaboticabal: FUNEP, 1994. 409p.

COSTA, A.C. Medidas morfométricas na avaliação de pesos e rendimentos corporais de pacu Piaractus mesopotamicus e tambaqui Colossoma macropomum. 2011. 64f. Dissertação (Mestrado em Zootecnia) - Universidade Federal de Lavras, Lavras.

FARIA, R.H.S.; SOUZA, M.L.R.; WAGNER, P. M. et al. Rendimento do processamento da tilápia do Nilo (Oreochromis niloticus Linnaeus, 1757) e do pacu (Piaractus mesopotamicus Holmberg, 1887). Acta Scientiarum. Animal Sciences, v.25, n.1, p.21-24, 2003.

HOHENBOKEN, W.D. Maternal effects. In: CHAPMAN, A.B. (Ed.) General and quantitative genetics. Wisconwin: University of Wisconsin, 1894. Cap. 7, v.4, p.135-147.

INSTITUTO BRASILEIRO DO MEIO AMBIENTE E DOS RECURSOS NATURAIS RENOVÁVEIS - IBAMA. Diretoria de Fauna e Recursos Pesqueiros. Estatística da pesca, 2005: Grandes regiões e unidades da federação. Brasília: IBAMA, 2005. p.147.

KUBITZA, F. Qualidade da água no cultivo de peixes e camarões. 1.ed. Jundiaí: Gráfica Editora Degaspari, 2003. 229p.

KUBTIZA, F. Coletânea de informações aplicadas ao cultivo do tambaqui, do pacu e de outros peixes redondos. Panorama da Aqüicultura, v.14, n.82, p.27-39, 2004.
MINISTÉRIO DA PESCA E AQUICULTURA - MPA. Produção pesqueira e aquícola - Estatística 2008 e 2009. Brasília, 2010. p.129.

NIELSEN, H.M.; ØDEGÅRD, J.; OLESEN, I. et al. Genetic analysis of common carp (Cyprinus carpio) strainsI: Genetic parameters and heterosis for growth traits and survival. Aquaculture, v.304, p.14-21, 2010.

POPMA, T.J.; PHELPS, R.P. Status report to commercial tilápia producers on monosex fingerling productions techniques. In: AQUICUlTURA BRASIL, 10., 1998, Recife. Anais... Recife: Associação Brasileira de Aquicultura, 1998. p.127-145.

RUTTEN, M.J.M.; BOVENHUI, H.; KOMEN, H. Modeling fillet traits based on body measurements in three Nile tilapia strains (Oreochromis niloticus L.). Aquaculture, v.231, p.113-122, 2004.

SILVA,F.V.; SARMENTO, N.L.A.F.; VIEIRA, J.S. etal. Características morfométricas, rendimentos de carcaça, filé, vísceras eresíduos em tilápias-do-nilo em diferentes faixas de peso. Revista Brasileira de Zootecnia, v.38, n.8, p.1407-1412, 2009.

SILVA, R.F.; TORRES, R.A.; RIBEIRO-FILHO, O. et al. Avaliação genética do crescimento de tilápia do Nilo em condições de baixa temperatura. Zootecnia Tropical, v.28, n.3, p.395-401, 2010.

SOUZA, A.F.L. Rendimento, composição química e perfil de minerais das principais espécies de peixes comercializadas no estado do Amazonas. 2008. 132f. Dissertação (Mestrado em Ciências Agrárias) - Universidade Federal do Amazonas, Manaus.

WACHIRACHAIKARN, A.; RUNGSIN, W.; SRISAPOOME, P.; NA-NAKORN, U. Crossing of African catfish, Clarias gariepinus (Burchell, 1822), strains based on strain selection using genetic diversity data. Aquaculture, v.290, p.53-60, 2009.

WEIGENSBERG, I.; CARRIÉRE, Y.; ROFF, D.A. Effects of male genetic contribution and paternal investment to egg and hatchling size in the crichet, Gryllus firmus. Journal of Evolutionary Biology, v.11, p.135-146, 1998. 